\title{
HUBUNGAN ANTARA DUKUNGAN KELUARGA DENGAN TINGKAT STRES NARAPIDANA DI LEMBAGA PEMASYARAKATAN WIROGUNAN YOGYAKARTA
}

\author{
${ }^{1}$ Baiti Nur Rizqiyani, ${ }^{2}$ Angga Eka Yuda, ${ }^{3}$ Galih Fajar Fadillah, dan \\ 4 Ernawati \\ 1,2,3 Bimbingan Konseling Islam, UIN Raden Mas Said Surakarta \\ ${ }^{4}$ Psikologi Islam, UIN Raden Mas Said Surakarta \\ 1'baitirizqiya@gmail.com, ${ }^{2}$ anggaeyw17@gmail.com,3 galihfajarf@gmail.com, \\ ${ }^{4}$ ernawatikonseling@gmail.com
}

\section{Abstract}

Unrelationship between people with their family make much of them stress, especially for a prisoner. For some prisoner, family is the safe place to presure their stress. Family support has a positive impact on the stress experienced by prisoners. The purpose of this study was to determine the relationship between family support and the stress level of prisoners in Prison Class II A Wirogunan Yogyakarta. This study uses a quantitative method with a correlational type. The population in this study were prisoners, amounting to 60 people. The research sample was taken using a total sampling technique. The data collection tool used a Likert scale from two variables, namely family support and stress levels. Hypothesis testing in this study used the Produt Moment correlation analysis. Based on the test results using Product Moment correlation analysis, it is known that the rxy value is -0.288 and the $p$-value is 0.026 ( $p<0.05)$ which indicates that there is a negative and significant relationship between family support variables and stress levels. The higher the family support received, the lower the level of stress experienced by prisoners before being released. In other world, the lower the family support received, the higher the stress. Meanwhile, the effective contribution of family support to the stress of prisoners before being released was $8.3 \%(r=0.083)$, which means that $91.7 \%$ of the inmates' stress towards being released was influenced by other variables besides family support. By obtaining moderate family support 42 (70\%), low 10 (21.67\%) and high (23.3\%) with moderate stress levels 34 (56.67\%), low and high respectively 13 (21.17\%). The variable level of family support is classified as moderate, the level of stress is also classified as moderate. It can be concluded that there is a relationship between family support and the stress level of prisoners before being released into the moderate category.

Keywords: Family Support, Level of Stress, Prisoners Before Release

\section{Abstrak}

Terputusnya hubungan dengan keluarga dapat mengakibatkan stres pada diri narapidana. Bagi beberapa narapidana keluarga menjadi tempat teraman untuk mengurangi tekanan. Dukungan keluarga memberikan dampak positif tehadap 
stres yang di alami narapidana. Tujuan dalam penelitian ini adalah untuk mengetahui hubungan antara dukungan keluarga dengan tingkat stres narapidana menjelang masa bebas tahanan di Lembaga Pemasyarakatan Kelas II A Wirogunan Yogyakarta. Penelitian ini menggunakan metode kuantitatif dengan jenis korelasional. Populasi pada penelitian ini adalah narapidana menjelang masa bebas tahanan yang berjumlah 60 orang. Pengambilan sampel penlitian menggunakan teknik total sampling. Alat pengumpulan data menggunakan skala likert dari dua variabel, yaitu dukungan keluarga dan tingkat stres. Uji hipotesis dalam penelitian ini menggunakan analisis korelasi Produt Moment. Berdasarkan hasil pengujian menggunakan analisis korelasi Product Moment, diketahui nilai $\mathrm{r}_{\mathrm{xy}}$ sebesar -0.288 dan $p$-value sebesar $0.026(\mathrm{p}<0.05)$ yang menunjukkan bahwa terdapat hubungan negatif dan signifikan antara variabel dukungan keluarga dan tingkat stres. Semakin tinggi dukungan keluarga yang diterima maka akan semakin rendah tingkat stres yang dialami narapidana menjelang bebas. Begitu juga sebaliknya, semakin rendah dukungan keluarga yang diterima, maka semakin tinggi pula stresnya. Sedangkan sumbangan efektif dukungan keluarga terhadap stres narapidana menjelang bebas sebesar 8,3\% ( $r=0,083)$ yang berarti sebesar $91,7 \%$ stres para narapidana mejelang bebas dipengaruhi oleh variabel lain selain dukungan keluarga. Dengan diperoleh dukungan keluarga sedang $42(70 \%)$, rendah $10(21,67 \%)$ dan tinggi $(23,3 \%)$ dengan tingkat stres sedang 34 (56,67\%), rendah dan tinggi masing-masing 13 (21,17\%). Tingkat variabel dukungan keluarga tergolong sedang, tingkat stres juga tergolong sedang. Dapat ditarik kesimpulan bahwa ada hubungan dukungan keluarga dengan tingkat stres narapidana menjelang bebas masuk dalam kategori sedang. Sedangkan berdasarkan distribusi frekuensi berdasarkan aspek masing-masing variabel dukungan keluarga dan tingkat stres dalam kategori baik.

Kata Kunci : Dukungan Keluarga, Tingkat Stres, Narapidana Jelang Bebas

\section{PENDAHULUAN}

Narapidana adalah orang yang dipidana berdasarkan putusan pengadilan yang telah memperoleh kekuatan hukum tetap. Dalam UU No.12 tahun 1995 tentang pemasyarakatan pasal 1 ayat 2, Lembaga Pemasyarakatan merupakan tempat untuk melakukan pembinaan narapidana dan anak didik pemasyarakatan. Pembinaan dengan konsep rehabilitas dan reintegrasi sosial agar narapidana menyadari kesalahannya, memperbaiki diri, tidak melakukan tindak pidana lagi, kembali menjadi warga masyarakat yang betanggung jawab bagi diri sendiri, keluarga dan lingkungan (hukum unsrat.a.id).

Berdasarkan data yang peneliti dapatkan dengan berbagai jenis tindak kejahatan dan berdasarkan tanggal masuk dan ekspirasi, sebanyak 239 narapidana yang ada, diantaranya 60 narapidana yang akan menjelang masa bebas. Menurut petugas Lapas narapidana bisa bebas apabila sudah memasuki masa 2/3 tahanan bisa mendapat remisi/bebas bersyarat apabila sudah sesui dengan persyaratan dan sudah berkelakuan baik. Masa menjelang bebas dan masa awal masuk tahanan menjadi moment paling banyak narapidana 
mengalami stres. Sukamto mengatakan bahwa terputusnya hubungan dengan keluarga membuat narapidana mengalami stres. Sama halnya dengan yang dikatakan oleh Fitriani (2008) bahwa lapas adalah tempat yang stresfull dimana narapidana mengalami pidana secara fisik dan psikologis (Dwi Saputra, Azza, Suryaningsih, 2016)

Keluhan-keluhan yang dirasakan narapidana seperti kehilangan kesempatan hubungan seksual, hak pribadinya, mendapatkan kebaikan dan bantuan, kerahasiannya akibat prasangka buruk dari masyarakat (Bukhori, 2012). Ketika narapidana menjalani masa hukuman dan jauh dari keluarga muncul perasaan-perasaan buruk yang melibatkan emsosinya, seperti perasaan kesepian, takut, gelisah, stres, dan putus asa. Dukungan sosial dari orang-orang terdekat seperti keluarga, kerabat, dan teman akan sangat berarti dalam meminimalisir gangguan psikologisnya. Sejumlah pendapat menurut (Dexy \& Woodal, 2012) menunjukan tentang pentingnya narapidana tetap berhubungan atau berinteraksi dengan keluarga mereka melalui kunjungan di penjara. Dukungan keluarga dapat menjadi penangkal (buffering) terhadap stres dalam berbagai peristiwa kehidupan. Dukungan yang diberikan keluarga berupa pemenuhan kebutuhan psikis yang meliputi kasih sayang, keteladanan, bimbingan dan pengarahan, dorongan, dan menanamkan rasa percaya diri. (Nelfice dkk, 2014).

Berdasarkan wawancara dengan salah satu narapidana di Lapas Wirogunan Jogja, narapidana tersebut merasa cemas dengan masa depannya ketika keluar dari Lapas nanti. Takut akan penolakan dari masyarakat, dikucilkan, dan takut tidak mendapatkan pekerjaan. Narapidana mengaku jarang sekali di besuk oleh keluarga, hal ini membuatnya merasa semakin takut adanya penolakan dari keluarga. Hal ini membuat narapidana stres dan tertekan. Berbeda dengan narapidana yang keluarganya rutin membesuk. Hal ini membuat narapidana merasa tetap mendapatkan kasih sayang dari keluarga meskipun terbatas. Ketika mendapat besukkan dari keluarga narapidana merasa punya semangat untuk tetap hidup dengan baik dan menjalani hukuman sesuai prosedur.

Peran keluarga sangatlah di perlukan dalam mendukung narapidana dalam menjalani hukuman. Berdasarkan wawancara salah satu narapidana yang tidak di besuk secara langsung, melainkan melalui telepon salah satu petugas Lapas. Hal ini juga bisa membantu narapidana untuk mengurangi rasa cemas, takut, dan stres. Karena secara tidak langsung keluarga tetap peduli dengan kondisi narapidana saat di Lapas. Dari hasil wawancara dengan beberapa narapidana diatas dapat ditarik kesimpulan, bahwa dukungan keluarga sangatlah diperlukan, alih-alih untuk mengurangi rasa cemas dan stres narapidana. Support dari keluarga juga sangat berpengaruh untuk 
narapidana dalam penerimaan diri narapidana, perubahan narapidana untuk menjadi lebih baik lagi.

Sejalan dengan penelitian yang dilakukan oleh (Ratnasari dkk, 2020) dalam penelitiannya menunjukkan bahwa ada hubungan positif antara dukungan keluarga dengan tingkat stres warga binaan dengan p value 0,000 (< Alpha $=0,05$ ). Sedangkan penelitian (Windistiar, 2016) menunjukkan adanya hubungan negatif antara dukungan sosial dengan stres terhadap narapidana perempuan dengan $(r=-0,424$, p $0,000<0,01)$ yang artinya semakin tinggi dukungan sosial maka semakin rendah stres yang dialami narapidana perempuan. Stres memang sudah menjadi bagian dari kehidupan yang tidak bisa dilepaskan dari kehidupan seseorang. Stres dapat diminimalisir dengan berbagai cara salah satunya dukungan keluarga. Faktor penentu berhasil atau tidaknya dukungan keluarga dalam meminimalisir permasalahan yang dihadapi yaitu narapidana itu sendiri.

Berdasarkan latar belakang di atas, maka peneliti tertarik untuk melakukan penelitian yang berjudul "Hubungan Antara Dukungan Keluarga Dengan Tingkat Stres Narapidana Menjelang Masa Bebas Tahanan Di Lembaga Pemasyarakatan Kelas II A Wirogunan Yogyakarta".

\section{METODE}

Tujuan penelitian ini adalah untuk mengetahui seberapa besar hubungan antara dukungan keluarga dengan tingkat stres narapidana menjelang masa bebas tahanan di Lembaga Pemasyarakatan Kelas II A Wirogunan Yogyakarta. Penelitian ini termasuk penelitian kuantitatif dengan metode korelasional yang dilaksanakan pada 10 Maret 2021 - selesai di Lembaga Pemasyarakatan Kelas IIA Wirogunan Yogyakarta. Sampel dalam penelitian ini adalah 60 narapidana menjelang bebas tahanan dengan teknik total sampling. Pengumpulan data dilakukan dengan menggunakan kuisioner yang terdiri dari dua bagian yaitu, kuisinoner dukungan keluarga dan kuisioner tingkat stres. Semua pernyatan menggunakan skala Likert dengan empat poin (1-4). Data diolah dengan cara editing, scoring, coding,entry.

Analisis data yang digunakan adalah analisis univariat yaitu mean, median, modus, standar deviasi, kemudian hasilnya dalam bentuk narasi dan tabel distribusi frekuensi, sedangkan analisis bivariat dilakukan dengan uji statistik kolmogrov smirnov.

\section{HASIL DAN PEMBAHASAN}

Berdasarkan hasil penelitian yang telah dilakukan terhadap 60 responden, didapatkan hasil sebagai berikut: 
Tabel 1. Dukungan Emosional Keluarga

\begin{tabular}{ccc}
\hline Kategori & F & \% \\
\hline Kurang Baik & 29 & 48.3 \\
Baik & 31 & 51.7 \\
\hline Total & 60 & 100.0
\end{tabular}

Berdasarkan tabel di atas, diketahui mayoritas responden memiliki skor pada aspek emosional dengan kategori baik yaitu sebanyak 31 orang dengan presentase sebesar 51.7\%. Sisanya yaitu sebanyak 29 orang atau $48.3 \%$ memiliki skor pada aspek emosional dengan kategori kurang baik.

Tabel 2. Dukungan Informasi Keluarga

\begin{tabular}{ccc}
\hline Kategori & F & \% \\
\hline Kurang Baik & 19 & 31.7 \\
Baik & 41 & 68.3 \\
\hline Total & 60 & 100.0 \\
\hline
\end{tabular}

Berdasarkan tabel di atas, diketahui mayoritas responden memiliki skor pada aspek informasi dengan kategori baik yaitu sebanyak 41 orang dengan presentase sebesar $68.3 \%$. Sisanya ialah sebanak 19 orang atau 31.7\% memiliki skor pada aspek informasi dengan kategori kurang baik.

Tabel 3. Dukungan Penilaian / Penghargaan Keluarga

\begin{tabular}{ccc}
\hline Kategori & F & \% \\
\hline Kurang Baik & 26 & 43.3 \\
Baik & 34 & 56.7 \\
\hline Total & 60 & 100.0 \\
\hline
\end{tabular}

Berdasarkan tabel di atas, diketahui mayoritas responden memiliki skor pada aspek penilaian dengan kategori baik yaitu sebanyak 34 orang dengan presentase sebesar 56.7\%. Sisanya ialah sebanyak 26 orang atau 43.3\% memiliki skor pada aspek penilaian dengan kategori kurang baik.

Tabel 4. Dukungan Instrumental Keluarga

\begin{tabular}{crr}
\hline Kategori & F & \% \\
\hline Kurang Baik & 24 & 40.0 \\
Baik & 36 & 60.0 \\
\hline Total & 60 & 100.0 \\
\hline
\end{tabular}

Berdasarkan tabel di atas, diketahui mayoritas responden memiliki skor pada aspek instrumntal dengan kategori baik yaitu sebanyak 36 orang dengan presentase sebesar $60 \%$. Sisanya ialah sebanyak 24 orang atau $40 \%$ memiliki skor pada aspek instrumental dengan kategori kurang baik. 
Tabel 5. Aspek Emosional Tingkat Stres

\begin{tabular}{ccc}
\hline Kategori & F & \% \\
\hline Kurang Baik & 29 & 48.3 \\
Baik & 31 & 51.7 \\
\hline Total & 60 & 100.0 \\
\hline
\end{tabular}

Berdasarkan tabel di atas, diketahui mayoritas responden memiliki skor pada aspek emosional dengan kategori baik yaitu sebanyak 31 orang dengan presentase sebesar 51.7\%. Sisanya ialah sebanyak 29 orang atau $48.3 \%$ memiliki skor pada aspek emosional dengan kategori kurang baik.

Tabel 6. Aspek Kognitif Tingkat Stres

\begin{tabular}{ccc}
\hline Kategori & F & \% \\
\hline Kurang Baik & 30 & 50.0 \\
Baik & 30 & 50.0 \\
\hline Total & 60 & 100.0 \\
\hline
\end{tabular}

Berdasarkan tabel di atas, diketahui jumlah responden yang memiliki skor baik dan kurang baik pada aspek kognitif ialah sama, yaitu masing-masing sebanyak 30 orang dengan presentase $50 \%$.

Tabel 7. Aspek Perilaku Sosial Tingkat Stres

\begin{tabular}{ccc}
\hline Kategori & F & \% \\
\hline Kurang Baik & 24 & 40.0 \\
Baik & 36 & 60.0 \\
\hline Total & 60 & 100.0 \\
\hline
\end{tabular}

Berdasarkan tabel di atas, diketahui mayoritas responden memiliki skor pada aspek perilaku sosial dengan kategori baik yaitu sebanyak 36 orang dengan presentase sebesar $60 \%$. Sisanya ialah sebanyak 24 orang atau $40 \%$ memiliki skor pada aspek perilaku sosial dengan kategori kurang baik.

Tabel 8. Aspek Fisiologis Tingkat Stres

\begin{tabular}{ccc}
\hline Kategori & $\mathrm{F}$ & $\%$ \\
\hline Kurang Baik & 28 & 46.7 \\
Baik & 32 & 53.3 \\
\hline Total & 60 & 100.0 \\
\hline
\end{tabular}

Berdasarkan tabel di atas, diketahui mayoritas responden memiliki skor pada aspek fisiologis dengan kategori baik yaitu sebanyak 32 orang dengan persentase sebesar 53.3\%. Sisanya ialah sebanyak 28 orang atau $46.7 \%$ memiliki skor pada aspek fisiologis dengan kategori kurang baik. 
Berdasarkan tabel di atas, tingkat dukungan keluarga yang diperoleh narapidana pada aspek dukungan emosional adalah dalam kategori baik yaitu sebesar 31 responden (51.7\%). Pada aspek dukungan informasi adalah dalam keadaan baik yaitu sebesar 41 responden (68,3\%). Pada aspek dukungan penilaian adalah dalam kategori baik yaitu sebesar 34 responden $(56,7 \%)$. Pada aspek dukungan instrumental adalah dalam kategori baik sebesar 36 responden $(60 \%)$.

Sedangkan gambaran tingkat stres yang diperoleh narapidana pada aspek emosional adalah dalam kategori baik yaitu sebesar 31 responden (51,7\%). Pada aspek kognitif adalah dalam kategori baik yaitu sebesar 30 responden (50\%). Pada aspek perilaku sosial adalah dalam kategori baik sebesar 36 responden (60\%). Pada aspek fisiologis adalah dalam kategori baik yaitu sebesar 32 responden (53,3\%). Dapat ditarik kesimpulan dari hasil penelitian berdasarkan distribusi frekuensi berdasarkan aspek masing-masing variabel dukungan kelurga dan tingkat stres dalam kategori baik.

Setiap manusia tentunya mempunyai harapan kehidupan yang baik dan bahagia. namun dalam prosesnya tidak dilalui dengan mudah, dan sesuai dengan harapan. Seperti halnya narapidana, menjadi seorang narapidana menjadi beban tersendiri bagi narapidana tersebut dan keluarga. Narapidana berharap ketika bebas nanti bisa menjadi seseorang yang lebih baik, kembali kedalam masyarakat, bekerja yang halal dan mempunyai kehidupan yang normal. Stigma negatif masyarakat terhadap narapidana mengakibatkan munculnya sikap pesimis bagi narapidana untuk kembali di lingkungan sosialnya. Beberapa masyarakat beranggapan bahwa narapidana yang telah berada di rumah tahanan masih mempunyai kecenderungan untuk menjadi residivis. Hal ini akan membuat seorang narapidana setelah bebas dari tahanan tidak memperoleh hak kemanusiannya kembali dalam masyrakata atau terdiskriminasi (Akhyar, Matnuh, Najibuddin, 2014).

Lembaga Pemasyarakatan Kelas II A Wirogunan Yogyakarta adalah lembaga pemasyarakatan yang khusus melaksanakan pembinaan terhadap narapidana laki-laki. Lapas Wirigunan dalam pembinaan dilakukan dengan tiga tahap yaitu tahap awal, tahap lanjutan 1, dan tahap pembinaan lanjutan 2 . Pembinaan dengan konsep rehabilitasi dan reintegrasi sosial agar narapidana menyadari kesalahannya, memperbaiki diri tidak lagi melakukan tindak pidana dan kembali menjadi warga masyarakat yang bertanggung jawab bagi diri sendiri dan keluarga.

Petugas Lapas mengatakan bahwa terputusnya hubungan dengan keluarga membuat narapidana merasa stres. Saat menjalani masa pidana di Lapas kondisi kepribadian narapidana cukup buruk. Keadaan ini akan menimbulkan tekanan tersendiri pada diri narapidana, hal tersebut akan 
memungkinkan narapidana mengalami stress dan merasakan ketidaknyamanan (Lailatun Nur \& Shanti K, 2013). Ketika harus tinggal di Lapas segala ruang gerak pada narapidana sangatlah terbatas. Di dalam Lapas narapidana diberikan pelatihan bimbingan kerja seperti ketrampilan musik, batik, potong rambut, menjahit, furniture dan servise elektronik.

Aktivitas yang dilakukan narapidana tidak menutup kemungkinan membuat narapidana di dalam Lapas merasakan stres, meskipun pembinaan dalam bentuk kegiatan telah di berikan kepada narapidana. Selain itu stres bisa terjadi akibat terbatasnya ruang gerak dan terisolasi dari masyarakat (Nuria, 2016).

Perubahan keadaan yang jauh dari orang-orang terdekat menimbulkan narapidana rentan terkena gangguan psikologis. Narapidana selalu memikirkan image dari masyarakat yang kurang baik terhadap dirinya. Kondisi yang tidak seimbang dengan perasaan negative yang dirasakan oleh narapidana tidak jarang akan berdampak lebih kuat kepada psikologisnya. Narapidana akan mengalami depresi. Dukungan keluarga sangat berarti bagi narapidana agar tetap semangat menjalani hidup dan terhindar dari stres. Keluarga dapat berperan sebagai pemberi dukungan sosial dan membantu individu ketika suatu masalah muncul. Dukungan keluarga dapat berupa dukungan yang barasal dari internal ataupun eksternal (Purnama Sari, 2017).

Faktor-faktor yang mempengaruhi terjadinya stress narapidana ialah sulit beradaptasi dan menerima kenyataan, jauh dari keluarga, dijauhi oleh lingkungan sosialnya, serta memiliki kebebasan yang terbatas. Kondisi yang serba terbatas membuat narapidana ingin segera bebas, akan tetapi di sisi lain narapidana merasa takut untuk bebas karena adanya penolakan sosial, pengasingan, dan pengucilan dari masyarakat serta sulitnya mendaptkan pekerjaaan. Hal ini membuat narapidana tidak siap untuk menjalin kehidupan baru setelah bebas dari masa hukuman (Wulan \& Ediati, 2019).

Narapidana yang merasa tertekan serta memiliki pikiran negative tentang dirinya dan lingkungan sekitarnya akan membuat buruk keadaan sehingga sulit untuk meningkatkan kualitas hidupnya. Salah satu faktor yang dapat meminimalisir stress narapidana adalah adanya dukungan dari keluarga. Karena dukungan keluarga akan menimbulkan ketenangan batin dan perasaan senang dalam diri indidvidu.

Berdasarkan hasil perhitungan teknik analis product moment dari Carl Pearson diperoleh nilai koefisien korelasi $\left(\mathrm{r}_{\mathrm{xy}}\right)$ sebesar -0.288 dengan Sig.= 0,000 ( $\mathrm{p}<0.05$ ), yang artinya ada hubungan negatif yang sangat signifikan antara dukungan keluarga dengan tingkat stres. Yang artinya bahwa semakin tinggi dukungan keluarga maka semakin rendah tingkat stres pada narapidana menjelang masa bebas tahanan, sebaliknya semakin rendah dukungan keluarga 
maka semakin tinggi tingkat stres pada narapidana menjelang masa bebas tahanan.

Sejalan dengan hasil penelitian yang pernah di lakukan oleh (Windistiar, 2016) menunjukkan adanya hubungan negatif antara dukungan sosial dengan stres terhadap narapidana wanita $(r=-0.424 ; p=0,000)$. Yang berarti bahwa semakin tinggi dukungan sosial maka semakin rendah stres yang dialami narapidana perempuan. Dukungan sosial yang diberikan dapat membantu narapidana measa lebih tenang, merasa di perhatikan, dicintai, dan merasa percaya diri.

Dukungan keluarga (Friedman, 2010) merupakan suatu yang bersifat mendukung. Selalu siap memberikan pertolongan dan bantuan jika dibutuhkan dalam kondisi apapun. Dukungan keluarga dapat berupa dukungan yang barasal dari internal ataupun eksternal. Dukungan internal sendiri meliputi dukungan dari suami/istri, anak, saudara kandung. Sedangkan dukungan eksternal berupa dukungan dari sahabat, tetangga, tempat ibadah, sekolah, dan praktisi kesehatan. (Purnama Sari, 2017).

Dukungan keluarga sangat berarti bagi narapidana agar tetap semangat menjalani hidup dan terhindar dari stres. Keluarga dapat berperan sebagai pemberi dukungan sosial dan membantu individu ketika suatu masalah muncul. Dengan demikian dapat disimpulkan bahwa dukungan keluarga dari orang-orang disekitar berpengaruh pada tingkat stres yang dialami narapidana dalam menghadapi masa pembebasan.

Sedangkan hasil analisis data yang telah dilakukan menunjukkan bahwa Dukungan Keluarga narapidana menjelang masa bebas tahanan berbeda-beda, dan dari hasil analisa diketahui bahwa 42 orang dalam kategori dukungan keluarga sedang dengan presentase sebesar $70 \%$, sedangkan 10 orang dalam kategori dukungan keluarga rendah dengan presentase $6.67 \%$ dan sisanya 8 orang dalam kategori dukungan keluarga tinggi dengan presentase 13,3\%. Berdasarkan dari analisa, bahwa tingkat dukungan keluarga narapidana menjelang masa bebas tahanan di Lembaga Pemasyarakatan Kelas II A Wirogunan Yogyakarta dalam kategori sedang.

Dukungan keluarga yang didapatkan oleh para narapidana sangat berpengaruh pada tingkat stres narapidana dalam menghadapi masa menjelang bebas, hal ini sejalan dengan penelitian yang dilakukan oleh Permana (2013), bahwa ada hubungan antara dukungan keluarga dengan tingkat stres pada lansia dengan $\mathrm{p}$ value 0,000. Lansia yang memiliki dukungan keluarga baik, memiliki tingkat stres yang lebih ringan jika dibandingkan dengan lansia yang memiliki dukungan keluarga kurang baik. Lansia dengan dukungan keluarga baik berpeluang 0,67 kali memiliki tingkat stres yang lebih ringan daripada lansia dengan dukungan keluarga yang tidak baik. 
Stres pada individu dapat menimbulkan dampak berupa, upaya individu melakukan reaksi terhadap stres atau respon terhadap stres. Pandangan Suliswati (2005) ; Syahradhani,dkk, (2020) mengatakan bahwa stres merupakan suatu gangguan pada tubuh dan mental bahwa stres merupakan suatu gangguan pada tubuh dan mental seseorang dimana disebabkan karena tuntutan kehidupan, sedangkan stres juga dapat terjadi dimana saat keadaan tidak terdapat tuntutan dan menjadikan seseorang bosan atau frustasi.

Penelitian yang dilakuan oleh Miftahul Ima, dkk, (2016), analisis data pada kunjungan keluarga dan dukungan keluarga didapatkan bahwa sebagian besar mempunyai kunjungan dan dukungan baik yaitu 16 (40,0\%) dan tingkat stres sebagian besar tingkat ringan 17 (42,5\%). Diketahui bahwa ada hubungan antara kunjungan dan dukungan keluarga dengan tingkat stres yaitu $\mathrm{P}$ value $(\alpha=0,05)$. Melalui penelitian ini direkomendasikan kepada keluarga untuk memberikan motivasi atau dukungan kepada narapidana dengan mengunjungi secara rutin.

Sama halnya seperti penelitian lainnya yang dilakukan oleh (Susanti, Suryani, 2010) bahwa ada hubungan antara dukungan sosial dengan stres pada narapidana penyalahgunaan NAPZA di Lembaga Pemasyarakatan Narkotika Kelas II A Sleman Yogyakarta. Semakin besar dukungan sosial yang diterima narapidana tersebut maka tingkat stres lebih rendah, dan semakin kecil dukungan sosial yang diterima maka tingkat stres lebih tinggi.

Selain itu berdasarkan distribusi frekuensi berdasarkan aspek dukungan keluarga dan aspek tingkat stres yang masing-masing terdapat 4 aspek. Dukungan emosional keluarga berdasarkan tabel 1 dapat diketahui bahwa 31 responden (51.7\%) memiliki dukungan emosional yang baik. Dukungan emosional bahwa keluarga sebagai tempat yang aman, damai, serta membantu penguasaan terhadap emosi. Dukungan emosional ini meliputi pemberian semangat, perhatian, rasa empati, mendengarkan dan didengarkan, serta adanya kepercayaan (Cahyati, 2020).

Sejalan dengan penelitian yang dilakukan oleh Regina (2016) tentang hubungan dukungan keluarga dengan tingkat kecemasan pada narapidana mengatakan bahwa dukungan emosional keluarga berada pada kategori baik yaitu sebanyak 38 orang (54.5\%) (Sari \& Rachmalia, 2017). Berbanding terbalik dengan penelitian yang dilakukan oleh (Sulastri \& Mustikasari, 2013) bahwa dalam penelitian yang dilakukannya terdapat dukungan emosional keluarga berada pada kategori rendah sebanyak 25 orang (51\%). Dukungan emosional didapatkan ketika seseorang tersebut mempercayai, menghargai dan memahami dirinya sendiri dengan baik. Dukungan emosional yang akan diberikan membuat narapidana merasa ada yang memperhatikan, memperdulikan dan mendapat kasih sayang yang tulus. 
Dukungan informasional keluarga berdasarkan tabel 2 dapat diketahui bahwa 4 responden (68.3\%) memiliki dukungan informasional keluarga baik. Dukungan informasional keluarga sangat diperlukan oleh seorang narapidana saat mereka terpuruk di dalam tahanan. Dukungan informasional yaitu keluarga berfungsi sebagai pemberi informasi dimana keluarga menjelaskan tentang pemberian saran, sugesti, serta informasi yang dapat digunakan dalam mengungkapkan suatu masalah (Cahyati, 2020).

Penelitian ini sejalan dengan penelitian yang dilakukan oleh Rozi (2014) tentang hubungan dukungan keluarga dengan tingkat depresi narapidana mengatakan bahwa tingkat dukungan informasional berada pada kategori baik dengan 37 responden $(82,2 \%)$ dari 45 responden (Sulastri \& Mustikasari, 2013). Salah satu yang mempengaruhi dukungan keluarga yaitu interaksi dan komunikasi yang baik antar anggota keluarga. Mengingat keluarga adalah wadah pertama ketika seseorang tertimpa masalah.

Berbanding terbalik dengan penelitian yang di lakukan oleh Sulastri \& Mustikasari (2013) yaitu tentang dukungan sosial dengan tingkat stres anak pidana di Lapas Anak Pria Tangerang, dalam penelitian ini justru diperoleh bahwa dukungan informasional dalam kategori rendah yaitu sebanyak 33 responden (67.3\%) dari 49 responden. Dukungan keluarga berperan penting dalam meminimalisir dampak negatif stres dan presepsi penerimaan dukungan keluarga dipengaruhi oleh beberapa faktor seperti faktor dari penerima dukungan keluarga, pemberi dukungan keluarga dan jaringan sosial yang dimiliki dalam lingkungan tersebut (Sulastri \& Mustikasari, 2013).

Dukungan penilaian atau penghargaan berdasarkan tabel 3 dapat diketahui bahwa 34 responden (56.7\%) memiliki dukungan penilain atau pengahargaan dalam kategori baik. Dukungan penilaian/penghargaan keluarga berperan membimbing dan menengahi pemecahan masalah. Dukungan penilain yang baik dapat diberikan berupa support, penghargaan, dan perhatiaan (Cahyati, 2020). Hasil penelitian ini sejalan dengan penelitian yang dikakukan oleh (Regina 2016) tentang hubungan dukungan keluarga dengan tingkat kecemasan pada narapidana mengatakan bahwa dukungan penilaian keluarga berada pada kategori baik yaitu sebanyak 38 responden (54.5\%) (Purnama Sari, 2017).

Dukungan instrumental keluarga berdasarkan tabel 4 diketahui bahwa 36 responden (60\%) memiliki dukungan instrumental keluarga yang baik. Keluarga merupakan sumber pertolongan yang praktis dan konkrit. Seperti dalam hal kebutuhan keuangan, makan, minum dan istirahat. Penelitian ini sejalan dengan penelitian yang dilakukan oleh (Purnama Sari, 2017) tentang dukungan keluraga pada narapidana di rumah tahanan Negara kelas II B Banda Aceh, menyatakan bahwa 53 responden (71.6\%) memiliki dukungan 
instrumental yang baik. Penelitian ini berbanding terbalik dengan penelitian yang dilakukan oleh Sulastri 2013 dimana dukungan instrumental berada pada kategori rendah yaitu sebnayak 27 orang (55.1\%).

Menurut Sarafino 1994 mengatakan bahwa hambatan dalam pemberian dukungan instrumental antara lain keterbatasan sumber daya yang dimiliki oleh calon pemberi dukungan (Purnama Sari, 2017). Selain itu keluarga berpikir bahwa di dalam tahanan narapidana sudah terpenuhi kebutuhan sandang dan pangannya. Fakta dilapangan yang peneliti lihat kebutuhan yang diberikan oleh pihak lapas juga terbatas. Semua kembali kepada kesadaran keluarga masing-masing. Jika keluarga peduli maka kebutuhan narapidana pun juga akan terpenuhi dan sebaliknya. Namun dalam penelitian ini diperoleh bahwa dukungan instrumental yang diberikan pada napi dalam kategori baik.

Selain distribusi dukungan kelurga diperoleh pula distribusi tingkat stres. Hasil penelitian ini secara umum menunjukkan bahwa responden mengalami tingkat stres sedang. Hal ini juga dipengaruhi oleh dukungan keluarga yang diberikan dan faktor lainnya. Crewe (2009) mengatakan bahwa narapidana melakukan adaptasi positif dengan melakukan adaptasi positif terhadap stresor, mengikuti semua peraturan yang ada dan memiliki rasa antusias yang tinggi dalam melakukan aktifitas selama di lapas. Sedangkan adaptasi negatif terlihat narapidana yang masih merasa bersalah, menyesali perbuatannya, bertindak agresif dan menyendiri dari kehidupan lapas (Sulastri \& Mustikasari, 2013).

Peneliti berasumsi bahwa stres yang di alami narapidana di dalam lapas yang mana tergolong sedang. Yang mana stres sedang berlangsung selama beberapa hari. Hal ini bisa terjadi karena sudah bisa menerima kenyataan dan hukuman yang diberikan, sudah mulai bisa beradaptasi dengan lingkungan sekitar, dan mendapatkan support yang baik dari lingkungan sekitar.

Berdasarkan uraian diatas dapat disimpulkan bahwa dukungan keluarga dengan tingkat stres pada narapidana menjelang bebas dalam kategori sedang. Berdasarkan data distribusi frekuensi berdasarkan aspek dukungan keluarga dengan subvariabel dukungan emosional didapatkan responden (51.7\%) dalam kategori baik, dukungan informasi didapatkan 41 responden (68.3\%) dalam kategori baik, dukungan penilaian didapatkan 34 responden (56.7\%) kategori baik dan dukungan instrumental didapatkan 36 responden (60\%) juga dalam kategori baik.

Sedangkan berdasarkan aspek tingkat stres dengan subvariabel aspek emosional diketahui sebanyak 31 responden (51.7\%) dalam kategori baik, berdasarkan aspek kognitif diperoleh hasil yang seimbang masing-masing 30 responden (50\%) dalam kategori baik, sedangkan berdasarkan aspek fisiologis juga dalam kategori baik yaitu sebanyak 32 responden (53.3\%). 
Hasil penelitian ini bertujuan untuk mengetahui hubungan antara dukungan keluarga dengan tingkat stres narapidana menjelang masa bebas tahanan di Lembaga Pemasyarakatan Kelas II A Wirogunan Yogyakarta, di buktikan dengan uji hipotesis menggunakan korelasi Product Moment dari Parson, diketahui nilai $\mathrm{r}_{\mathrm{xy}}$ sebesar 0.288 dan $p$-value sebesar $0.026(\mathrm{p}<0.05)$ yang artinya Ha diterima dan Ho ditolak sehingga dapat disimpulkan bahwa terdapat hubungan yang negatif dan signifikan antara variabel dukungan keluarga dan tingkat stres. Selain berdasarkan $p$-value, pengambilan keputusan uji hipotesis dapat dilihat berdasarkan nilai $r_{\text {hitung dan }} r_{\text {tabel dengan }}$ menggunakan taraf sigifikansi $5 \%$ dan $\mathrm{N}=60$ diketahui nilia $\mathrm{r}_{\text {tabel }}$ sebesar 0.2542 dan $r_{\text {hitung }}$ sebesar 0.288 sehingga $r_{\text {hitung }}>r_{\text {tabel }}$ yang artinya Ha diterima dan Ho ditolak.

Berdasarkan nilai tersebut dapat disimpulkan bahwa terdapat hubungan antara kedua variabel penelitian. Adapun koefisien korelasi sebesar 0.288 menunjukkan adanya hubungan yang berlawanan antara dukungan keluarga dengan tingkat stres. Semakin tinggi dukungan keluarga yang diterima, maka akan semakin rendah tingkat stres yang dialami. Sebaliknya semakin rendah dukungan keluarga yang diterima, maka akan tinggi pula stresnya. Sedangkan sumbangan efektif dukungan keluarga terhadap stres narapidana menjelang bebas sebesar 8.3\% $(r=0,083)$ yang berarti sebesar 91.7\% stres pada narapidana menjelang bebas dipengaruhi oleh variabel lain selain dukungan keluarga.

Berdasarkan uraian diatas dapat disimpulkan bahwa dukungan keluarga berpengaruh terhadap tingkat stres. Dukungan keluarga yang di terima oleh narapidana akan membantu narapidana merasa tenang, merasa di cintai, mendapat kasih sayang, diperhatikan dan muncul rasa percaya diri yang tinggi. Dukungan keluarga dapat meminimalisir stres. Ketika seorang narapidana menghadapi suatu masalah dan narapidana menerima cukup dukungan keluarga, hal tersebut membuat narapidana tidak sendiri dalam menghadapi permasalahan yang sedang dihadapi. Karena ada seseorang yang memberikan dukungan kepada dirinya, seseorang yang memberikan masukan atau solusi, nasihat, kritik saran, kepedulian dan kasih sayang terhadap permasalahan yang dihadapi.

Meskipun dalam pemberian solusi ataupun saran tidaklah menemukan titik terang, akan tetapi setidaknya sedikit jauh lebih baik dan membantu narapidana untuk meringankan beban, mengurangi perasaan tertekan sedikit berkurang. Ketika narapidana mendapatkan kunjungan secara rutin dan cukup, hal ini akan memberikan hal positif kepada narapidana. Untuk membangun kepercayaan tinggi akan dirinya, merasa diperhatikan, dan membuat 
narapidana dirasa oleh keluarga dan masih ada ikatan yang kuat dengan keluarga.

Stres yang dialami narapidana di dalam Lapas dalam kategori sedang. Tingkat stres sedang hanya terjadi dalam beberapa hari. Narapidana dalam kondisi stres sedang bisa terjadi karena masa hukuman yang diberikan sudah bisa diterimanya. Ketika sudah bisa menerima hukuman yang sudah diberikan, narapidana juga akan merasa sudah bisa beradabtasi dengan lingkungan sekitar mereka. Keterbiasaan yang sudah dan jalani ini juga akan berpengaruh terhadap stres narapidana.

\section{KESIMPULAN}

Narapidana yang akan bebas mengalami berbagai permasalahan salah satunya terkait dengan penerimaan masyarakat terlebih lagi berkaitan dengan dukungan keluarga. Berdasarakan penelitian yang telah dilakukan dukungan keluarga memiliki pengaruh terhadap tingkat stres narapidana. Dengan kata lain semakin tinggi dukungan keluarga yang diterima, maka akan semakin rendah tingkat stres yang dialami. Sebaliknya semakin rendah dukungan keluarga yang diterima, maka akan tinggi pula stresnya. Sedangkan sumbangan efektif dukungan keluarga terhadap stres narapidana menjelang bebas sebesar 8.3\% ( $r=0,083$ ) yang berarti sebesar $91.7 \%$ stres pada narapidana menjelang bebas dipengaruhi oleh variabel lain selain dukungan keluarga.

\section{DAFTAR PUSTAKA}

Akhyar, Matnuh, Najibuddin, Z. (2014). Persepsi Mayarakat Terhadap Mantan Narapidana Di Desa Benua Jingah Kecamatan Barbari Kabupaten Hulu Sungai Tengah . Jurnal Pendidikan Kewarganegaraan, Vol 4, No 7, Mei

Cahyati, L. (2020). Hubungan Dukungan Keluarga Dengan Tingkat Kecemasan Pasien Pre Operasi General Anesti Di RS PKU Muhammadiyah Gamping . Skripsi.

Dwi Saputra, Azza, Suryaningsih, D. (2016). Hubungan Dukungan Keluarga Dengan Harga Diri Narapidana Di Lembaga Pemasyarakattan Klas II A Jember.

Khairani \& Ariesa, R. Y. (2019). Analisis Faktor-Faktor Yang Mempengaruhi Tingkat Kriminalitas Sumatera Utara (Pendekatan Ekonomi). kajian ekonomi dan kebijakan publik.

Lailatun Nur \& Shanti K, A. \&. (2013). kesepian pada narapidana lp. kedungpanen semarang ditinjau dari dukungan sosial keluarga dan status perkawinan. jurnal psikologi unissula semarang. 
Miftahul Ima, dkk. (2016). Hubungan Kunjungan Dan Dukungan Keluarga Dengan Tingkat Stres Pada Narapidana Di Lembaga Pemasyarakatan Kelas II A Jember. Jurnal Kesehatan .

(n.d.). Retrieved maret rabu, 2020, from hukum unsrat.a.id: hukum.unsrat.ac.id/uu/uu_12_95.htm

Nelfice dkk, N. V. (2014). Hubungan Dukungan Keluarga Dengan Harga Diri Remaja. JOM PSIK Vol.1 No.3 Oktober

Ningrum, R. A. (2019). Gambaran Penerimaan Diri Narapidana Wanita Di Lapas Tanjung Gusta Kelas IIA Medan. Skripsi 102.

Nuria, M. W. (2016). Perbedaan Tingkat Sres Narapidana Di Lembaga Pemasyarakatan Klas IIA Jember Di Tinjau Dari Lembaga Vonis. SKRIPSI.

Purnama Sari, Rahmalia, H. (2017). Dukungan Keluarga Pada Narapidana Di Rumah Tahanan Negara Kelas II B Banda Aceh. Jurnal Kesehatan .

Ratnasari dkk, F. W. (2020). Dukungan Keluarga Dengan Tingkat Stress Warga Binaan Di Lembaga Pemasyarakatan Perempuan Tangerang. Edu Dharma Journal

Saputra Denny Dwi, Azza Awatiful, Suryaningsih Yeni. (2016). Hubungan Dukungan Keluarga Dengan Harga Diri Narapidana Di Lembaga Pemasyarakatan Klas II A Jember. Jurnal

Sari \& Rachmalia, H. (2017). Dukungan Keluarga Pada Narapidana Di Rumah Tahanan Negara Kelas II B Banda Aceh.

Segarahayu, R. D. (2013). Pengaruh Manajemen Stres Terhadap Penurunan Tingkat Stres Pada Narapidana Di LPW Malang. jurnal um.

Sulastri, Mustikasari. (2013). Dukungan Keluarga Dengan Tingkat Stres Anak Pidana Di Lapas Anak Pria Tangerang. Naskah Publikasi

Susanti Weni, Suryani. (2010). Hubungan Dukungan Sosial Dengan Stres Pada Narapidana Penyalahgunaan Napza Di Lembaga Pemasyarakatan Narkotika Kelas II A Sleman Yogyakarta. Naskah Publikasi

Syahradhani,dkk. (2020). Hubungan Antara Dukungan Keluarga Dengan Tingkat Stres Narapidana Di LPKA Kelas 1 Martapura. Artikel.

Windistiar, D. E. (2016). Hubungan Dukungan Sosial Dengan Stres Narapidana Wanita.Skripsi

Wulan \& Ediati, A. \&. (2019). Hubungan Antara Penerimaan Diri Dengan Kecemasan Pada Warga Binaan Pemasyarakatan Wanita Kasus Narkotika Di Kalimantan Timur. Jurnal Empati, Volume 8, Nomor 1, Januari 2019, Halaman 173-184. 
